But a sudden change, like that hinted at by our Begonia, was not contemplated by Mr. Darwin's hypothesis; and if such should ever be established; if seeds should ever be raised from such a flower, and should breed true, then the theory would receive a serious damage, and a few such cases would overthrow it altogether. For, says Mr. Darwin, at page 206, " on the theory of natural selection we can clearly understand the full meaning of that old canon in natural history, 'Natura non facit saltum.' This canon, if we look only to the present inhabitants of the world, is not strictly correct ; but if we include all those of past times, it must by my theory be strictly true." It might be easily shown, by quoting other passages, that the theory, strictly taken, denies not only a "saltus" but a "gradus," and proceeds by a sliding-scale. But let us confine ourselves to the "saltus." Is it not a "saltus" for a plant, at one bound, to change an inferior ovary and unisexual flowers to a superior ovary and bisexual? Would not such a fact, if fairly established in the vegetable world, be almost as wonderful as if a rhinoceros were born of an elephant? And are we quite sure that such a fact has not occurred in Nature? I merely throw out as a hint-not as asserting a truth, or even a probability, but merely as a hint, hypothetically put-that there are two natural orders of plants which have so many indications of common affinity that they were placed near together by Mr. Brown, but which differ from each other nearly by the very same characters as those by which our monstrous Begonia differs from its normal parent. The orders I allude to are Aristolochiaceæ and Nepenthaceæ. Aristolochiaceæ, like Begonia, has an inferior ovary of 3-6 carpels; Nepenthaceæ, like our monster, a superior ovary of 4 carpels. On theoretic principles, it is probable that Nepenthaceæ is the newest type ; for it is not, as yet, generically diversified, its flowers are 4-merous, its embryo more fully organized, and its geographical range more limited; and, as we are supposing, we may further guess that if Nepenthes were born "per saltum" from an Aristolochioid, it was some such genus as Trichopodium or Asiphonia that performed the part of cuckoo-parent. I use the term "cuckoo-parent" advisedly, for I should consider such an origin to be as true and as miraculous a creation (not " manufacture") of a new type as if it had pleased the Divine Creator to call up, without seed, from the dust of the ground, a new organism, by the power of his omnipotent word.-Gardener's Chronicle, Feb. 25, 1860.

\title{
The Monstrous Begonia frigida at Kew, in relation to Mr. Darwin's
} Theory of Natural Selection. By J. D. НоокеR, M.D.

Your ingenious correspondent, Dr. Harvey of Dublin, has noticed this remarkable plant in your last Number, and described the singular modifications of the floral organs as presenting a most decided "saltus." $\mathrm{He}$ proceeds to speculate on the importance of this case as affecting Mr. Darwin's theory, and, by what appears to me to be reasoning "per saltum," he arrives at the conclusion that "a few such cases would overthrow Mr. Darwin's hypothesis altogether!" Now I venture, on the contrary, to think that the "saltus" of this Begonia frigida has not the importance which Dr. Harvey imagines; and 
that, supposing (as he conceives possible) the seeds of the most aberrant flower to produce plants with similar flowers, the case would not even then militate against Mr. Darwin's theory, but the contrary. In the first place, let us attentively study this Begonia itself; its flowers are, like those of its congeners, normally unisexual, and produced in great abundance, both males and females, in the same fascicles all over the plant. The female flowers are perfectly constant in all their characters, except that they vary in having 3-4 cells and stigmas to the ovary and as many wings (which is not without precedent in the genus). The males have usually 6-15 stamens in the very centre of the flower, with no trace of stigmas or ovary; and not 10 per cent. present any deviation from this condition. Of those that do deviate, most have 3-5 deformed stamens or rudimentary ovaries in the axis of the flower, and proportionally fewer perfect stamens; and between the normal male flower and the very rare instances of a regular flower with four superior carpels (more or less united in the axis) and as many hypogynous stamens opposite the sepals, we find flowers with every conceivable modification in number, regularity, and perfection of stamens and carpels. Lastly, the abnormal carpels always bear very few ovules indeed, as compared with the normal ones. Now, it is very startling to be asked " is it not a 'saltus' for a plant at one bound to change an inferior ovary and unisexual flowers into a superior ovary and bisexual flowers?" but there is another way of putting the question, which is more accurate, however flat it may fall on the ear: viz., " is it a 'saltus' that a Begonia should produce male flowers, in a very few of which the central stamens are deformed, and in others are converted into more or less rudimentary or even perfect free or connate pistils?" So much for the plant. My friend proceeds to say that " according to Darwin's hypothesis it would have required hundreds, perhaps thousands, of successive generations to have enabled natural selection to convert an inferior ovary and unisexual flowers into a superior ovary and bisexual flowers." Mr. Darwin will, I think, demur to this, and still more to the rash assumption that, supposing any seeds of the hermaphrodite flowers of the Begonia should produce plants bearing none but hermaphrodite flowers, the latter would constitute even a new species amongst botanists, who would infallibly detect the true nature of the sport in this (as they have in similar cases), as soon as the normal state of the plant were known. In the first place, we do not know how many generations have elapsed since Begonia frigida commenced to bear any hermaphrodite flowers, nor how many generations may elapse before all traces of unisexual flowers will be obliterated in the progeny of a plant now bearing only about 5 per cent. of bisexual flowers; and it is to be borne in mind not only that these ovaries are incomparably the least prolific, but further, that, from being hermaphrodite, they are likely to be self-fertilized, and, according to Mr. Darwin's well-established observations, will hence give birth to a less numerous and less vigorous progeny. Nor must it be forgotten that this may be the lingering type of a by-gone phase of Begoniaceæ when all had superior oraries; for that it may be the 
last of an old race is as conceivable as that it is the first of a new one. An attentive study of the Begonia and a careful perusal of Darwin's book will, I am sure, convince your readers that this variation is a fact after that author's own heart. The fact of a metamorphosis so simple and common as that of stamens into carpels, suggesting to a first-rate botanist a new view of the affinity of the plant in which it occurs, is a very frequent one, and shows the imperfection of our knowledge and systems, not the magnitude or importance in the abstract of the changes that affect them. Instead of this being a case which (according to Dr. Harvey) "was not contemplated by Mr. Darwin's hypothesis," it is one of a class which he had specially in view; it is a beautiful illustration of the truth and wisdom of his chapter on classification, in which he shows how false are often the standards by which we estimate the value of characters; how loaded by preconceived ideas is the balance in which we weigh them; how prone, in short, we are to assume that a change is in itself fundamental, because it shakes our systems to the foundation. The differences between the extreme forms of the Begonia flowers are in no way comparable to those between "an elephant and a rhinoceros ;" nor do they lead us to imagine that the latter could ever be the progeny of the former. According to Darwin's hypothesis, the change from species to species must be slow, and is effected by the accumulation of small differences; this Begonia, assuming it to be the herald of a new type of Begoniacer, is a good instance of how slow and partial such a change is at the commencement; for it is confined to one set of organs in a very few flowers of one sex only, is conducted with the least possible disturbance of the functions of the plant, and there are prodigious odds against its ultimate success. We cannot indeed conceive the new form replacing the old till after the lapse of many generations, and a long course of that operation of natural selection which my friend thinks his forthcoming new type of Begoniaceæ has already dispensed with. Lastly, Dr. Harvey makes a most ingenious use of the abnormal flowers of the Begonia in seeking the affinity of the curious order to which it belongs; and assumes that it tends to place Begoniaceæ in the same alliance with Aristolochieæ and others, because it too includes genera with a superior and an inferior fruit; but amongst the many orders that share this peculiarity of the Begonia there is one much nearer to the position assigned to it (by Lindley first and by common consent since), and that is the alliance of Saxifrages : in these, and often in the same genus, we have superior and inferior ovaries *, free and connate carpels, with several modifications of placentation, epigynous, perigynous, and hypogynous stamens, the peculiar ovules of Begonia, its remarkable seeds, and its reticulated testa. Finally, to the same group also belongs Sempervivum, which offers another most curious instance of the conversion of stamens into carpels._Gardeners' Chronicle, Feb. 25, 1860.

* I need hardly remind the botanical reader that the conversion of staminiferous into pistilliferous flowers in unisexual trees is not uncommon, and that free superior carpels occur in species whose ovaries are normally inferior. 


\section{$2 \mathrm{BHL}$ Biodiversity Heritage Library}

Hooker, Joseph Dalton. 1860. "The monstrous Begonia frigida at Kew, in relation to Mr. Darwin's Theory of Natural Selection." The Annals and magazine of natural history; zoology, botany, and geology 5, 350-352.

View This Item Online: https://www.biodiversitylibrary.org/item/19558

Permalink: https://www.biodiversitylibrary.org/partpdf/39851

\section{Holding Institution}

Natural History Museum Library, London

\section{Sponsored by}

Natural History Museum Library, London

\section{Copyright \& Reuse}

Copyright Status: Public domain. The BHL considers that this work is no longer under copyright protection.

This document was created from content at the Biodiversity Heritage Library, the world's largest open access digital library for biodiversity literature and archives. Visit BHL at https://www.biodiversitylibrary.org. 